Article

\title{
Acacia Gum as a Natural Anti-Plasticizer for the Production of Date Syrup Powder: Sorption Isotherms, Physicochemical Properties, and Data Modeling
}

\author{
Nasim Mansoori ${ }^{1}{ }^{1}$, Mahsa Majzoobi ${ }^{1,2}$, Mohsen Gavahian ${ }^{3, * \mathbb{C}}$, Fojan Badii ${ }^{4}$ and \\ Asgar Farahnaky ${ }^{1,2}$ \\ 1 Department of Food Science and Technology, School of Agriculture, Shiraz University, Shiraz 7144165186, \\ Iran; nsm.mansoori@gmail.com (N.M.); mahsa.majzoobi@rmit.edu.au (M.M.); \\ asgar.farahnaky@rmit.edu.au (A.F.) \\ 2 Biosciences and Food Technology, School of Science, RMIT University, Bundoora West Campus, \\ Melbourne 3083, Australia \\ 3 Product and Process Research Center, Food Industry Research and Development Institute, No. 331 ShihPin \\ Rd., Hsinchu 30062, Taiwan \\ 4 Agricultural Engineering Research Institute (AERI), Agricultural Research, Education and Extension \\ Organization (AREEO), Karaj 31585-845, Iran; f.badii@areeo.ac.ir \\ * Correspondence: mohsengavahian@yahoo.com
}

Received: 31 October 2019; Accepted: 12 December 2019; Published: 5 January 2020

\begin{abstract}
The thermoplastic and hygroscopic behaviors of date syrup (DS) challenge the DS drying process. In this context, DS was mixed with 30\%, $40 \%, 50 \%$, and $60 \%$ acacia gum (AG) and subjected to a drum dryer. The chemical composition, bulk density $\left(p_{\mathrm{b}}\right)$, caking degree $(\mathrm{CD})$, glass transition temperature ( $\mathrm{Tg}$ ), and color values of DS powders were studied. The sorption isotherms were also obtained and compared to that of those predicted by mathematical models. According to the results, increasing the AG concentration enhanced the moisture content, $p_{\mathrm{b}}$, brightness, and Tg while it reduced the $\mathrm{CD}$ and equilibrium moisture sorption. All DS powders had type III isotherm behavior, i.e., similar to high-sugar foods. Guggenheim-Anderson-de Boer (GAB) and Peleg models were found to be suitable for fitting the experimental data and these models explained the monolayer moisture content decrease with increasing AG concentration. These results of the present study, for the first time, verified that the AG can be used as a natural anti-plasticizer agent for DS powder production.
\end{abstract}

Keywords: acacia gum; anti-plasticizer; date syrup; date powder; modeling; powder stability; palm date; physicochemical properties; Phoenix dactylifera; sorption isotherm

\section{Introduction}

The fruit of the palm tree (Phoenix dactylifera) has played a crucial role in providing energy and nutritional components, such as dietary fibers, minerals (selenium, copper, potassium, and magnesium), antioxidants (carotenoids and phenolics), and vitamins B and C, for humans during the past millennia [1,2]. The high-quality date fruit is consumed when it is fresh and can be stored for several weeks under controlled storage conditions [3]. Besides, about $50 \%$ of the harvested dates are considered as surplus dates and cannot be used fresh [4]. Therefore, the utilization of surplus dates can maintain sustainable date cultivation, reduce food waste, and result in economic benefits for palm farmers and the food industry.

Date syrup (DS) powder could be produced from surplus dates as a healthier alternative to refined sugar considering its health benefits, including anti-inflammatory, anticancer, and anti-mutagenic 
effects [5]; the chemical composition, such as high sucrose content [6]; and the relatively low price of the surplus dates [4]. However, it was reported that DS is very difficult to dry due to its thermoplastic and hygroscopic behavior [7]. It also contains high concentrations of fructose (31\%) and glucose (30\%) [8] with glass transition temperatures $(\mathrm{Tg})$ of -5 and $32{ }^{\circ} \mathrm{C}$, respectively $[9,10]$. Anti-plasticizers and hydrocolloids, such as starch and acacia gum (AG), have been utilized as support materials to enhance the $\mathrm{Tg}$ of sugar-rich foods during the dehydration process [7]. Anticaking agents are also commonly used to improve the resulted powder flowability $[9,11]$. Combinations of AG, modified starch, maltodextrin, and anticaking agents (e.g., tricalcium phosphate, and glycerol monostearate) have also been proposed to improve the drying process of high-sugar syrups $[9,12]$.

AG is the exudate from the acacia tree with stabilizing, emulsifying, and thickening properties [13-16]. This Codex Alimentarius-listed hydrocolloid [16] has been used as a drying agent in honey powder production and resulted in a product with low moisture content, good flowability, and physical properties [17]. Besides, good progress has been made in drying date fruit [18]. Also, in a previous study of our research team, the applicability of maltodextrin for date syrup drying was explored, which revealed the possibility of the production of date syrup powder by incorporating anti-plasticizers [19]. However, to the best of our knowledge, there is no published data on the potential application of AG as a processing aid in the production of DS powder. Thus, the current work aimed to investigate the effects of AG on the sorption isotherm and physicochemical properties of drum-dried DS and to determine the optimum concentration of this hydrocolloid, which results in a DS powder with enhanced physicochemical properties.

\section{Materials and Methods}

\subsection{Chemicals and Date Syrup}

The commercially produced syrup from the Kabkab date variety was provided by a local supplier in the south of Iran (Bushehr, Iran). According to the information provided by the supplier, the DS production includes date rehydrating, heating, mixing/crushing, separating the pulp from pits, and concentrating the product. The AG was supplied by a local supplier (Shojaiee Co., Shiraz, Iran). All the chemicals used in this work were of analytical grade and obtained from Merck Company (Darmstadt, Germany) unless otherwise specified.

\subsection{Preliminary Studies}

A set of preliminary tests were performed to figure out the appropriate range of AG concentration and the mixing conditions of syrup and gum. The minimum possible concentration of food additives (e.g. synthetic anti-plasticizer and anticaking agents) is usually preferred as they may negatively affect the product's sensory properties (e.g., flavor and color) [20]. On the other hand, an insufficient concentration of anti-plasticizer causes difficulties in scrapping off the dehydrated product from the drum dryer surface and results in a sticky powder that is difficult to process and handle [19]. To define the appropriate range of AG concentration, a wide range of this hydrocolloid $(5 \%, 10 \%, 20 \%, 30 \%, 40 \%$, $50 \%, 60 \%$, and $70 \%$ ) were mixed with the date syrup, and the process of drying and the dried products were carefully investigated based on a preliminary investigation. According to the results, a minimum of $30 \%$ of AG was required to produce a dry powder. In addition, the incorporation of $70 \% \mathrm{AG}$ in the formulation resulted in a product with unpleasant sensory properties. Therefore, the concentration of $\mathrm{AG}$ in the main experimental design ranged from $30 \%$ to $60 \%$. To find the appropriate mixing conditions, five minutes [19] of either mild (at ambient temperature) or warm (at $80{ }^{\circ} \mathrm{C}$ ) mixing before drum drying were evaluated. Afterward, the hot mixing condition was selected as the preferred method due to the more homogenous structure of the DS-AG mixture. 


\subsection{Sample Preparation}

The mixture of DS and AG was mixed thoroughly for $5 \mathrm{~min}$ (MKg magnetic stirrer, Wertheim, Germany) while heating to $80^{\circ} \mathrm{C}$. DS powders were produced from mixtures that contained four DS to AG ratios, i.e., 70:30, 60:40, 50:50, and 40:60 (dry basis). These mixtures were carefully poured over a roller dryer (Reliance, Frisco, TX, USA) with a diameter of $42 \mathrm{~cm}$ and a rotation speed of $4 \mathrm{rpm}$. This drier was preheated through steam circulation at the pressure of 2.3 bars and had a surface temperature of about $130^{\circ} \mathrm{C}$. The resulted dried film was surface scrapped, cooled down, and milled by a hammer mill. The resulting product was collected instantly and sealed in airtight polythene plastic bags to prevent the powders from absorbing the moisture of the environment. These plastic pouches were kept at room temperature before further analysis.

\subsection{Chemical Composition}

The protein, fat, ash, and dietary fiber content of the DS and AG were assessed according to the suggested methods by the Association of Official Analytical Chemists (AOAC) (AOAC, 2000). For moisture content determination, three grams of each sample were dried at $70{ }^{\circ} \mathrm{C}$ until constant weight by a laboratory oven [19]. To determine the ash content, about three grams of each sample were combusted in a muffle furnace (C-1500, Asangodaz, Iran) at $550{ }^{\circ} \mathrm{C}$ for eight hours. The Kjeldahl method was employed to measure the amount of nitrogen in the sample, which was then converted to the protein content using the conversion factor of 6.25. The amount of fat in samples was measured according to the weight loss of samples $(2 \mathrm{~g})$ after fat extraction by hexane in a Soxhlet apparatus (Fisher, Racine, WI, USA) at $60^{\circ} \mathrm{C}$ for $8 \mathrm{~h}$.

\subsection{Sugar Analysis}

Sugar molecules of the DS sample were analyzed using a Shimadzu high-performance liquid chromatography (HPLC) (Shimadzu, Japan) along with a Shimadzu LC-9A liquid chromatograph pump (Shimadzu, Japan), and a RID-6A refractive index detector (Shimadzu, Japan) along with a data processing system (Nelson Analytical Inc., Paramus, NJ, USA). An aliquot (5 $\mu \mathrm{L})$ of the filtered liquid was injected into an SCR-101N column of the HPLC system. A mixture of water and acetonitrile with a ratio of 20:80 and at a flow rate of $0.6 \mathrm{~mL} \cdot \mathrm{min}^{-1}$ was employed as the mobile phase to obtain high-resolution peaks of glucose, sucrose, and fructose. The runtime was $20 \mathrm{~min}$ and temperatures of both the detector and column were kept constant $\left(60^{\circ} \mathrm{C}\right)$. Standard solutions of glucose, sucrose, and fructose were used to prepare the calibration curves. The retention times of the peaks were compared with that of the standards injected at the same HPLC condition and quantified according to the regression equation, which was obtained from the standard samples [19].

\subsection{Bulk Density}

The ratio of the measured mass $(\mathrm{kg})$ to the volume $\left(\mathrm{m}^{3}\right)$ of the powder was defined as the bulk density $\left(p_{\mathrm{b}}\right)$ of the date powders [21]. In this regard, a cylindrical shape vessel with a diameter of $2.6 \times 10^{-2} \mathrm{~m}$ and a height of $4.1 \times 10^{-2} \mathrm{~m}$ was filled with the date powder sample. The vessel was tapped 4 times and a ruler was slid across the edge of the cylinder to remove any excess amount of powders. An analytical balance was used to measure the mass $(\mathrm{kg})$ of the date powder in the vessel. The vessel volume was calculated according to Equation (1):

$$
\mathrm{V}=\pi \mathrm{r}^{2} \mathrm{~h},
$$

where $V$ is the volume $\left(\mathrm{m}^{3}\right)$, and " $\mathrm{r}$ " and " $\mathrm{h}$ " are the radius $(\mathrm{m})$ and height $(\mathrm{m})$ of the vessel, respectively. 


\subsection{Caking Degree}

To determine the degree of caking $(\mathrm{CD})$, one gram of each powder was put in an airtight glass jar $(10 \mathrm{~mL})$ containing a supersaturated solution of sodium iodide (NaI). Therefore, the relative humidity inside the glass jar was $33 \%$. The jar was stored for a week at $25^{\circ} \mathrm{C}$ and regularly weighed using a laboratory scale (H20/A, Mettler, Zurich, Switzerland) to make sure moisture equilibrium condition is available inside the jar [22]. The powders were put in an isotope (281A, Fisherbrand, Hilden, Germany) under vacuum condition and at $70{ }^{\circ} \mathrm{C}$. The hydration process was continued to the time that successive weighing at 2-h intervals gave variation values of below $0.3 \%$. The dehydrated powders were then weighed and transferred into a sieve with a mesh size of $500 \mu \mathrm{m}$, which was shaken for five minutes. The mass $(\mathrm{kg})$ of the remaining powder on top of the sieve was measured and the $C D$ was determined according to Equation (2) [9].

$$
C D=\frac{a}{b} \times 100,
$$

where $C D$ is the caking degree (\%), and $b$ and $a$ are the total sample weight and the weight of the sample that remained on the sieve after the sieving process, respectively.

\subsection{Glass Transition Temperature}

The Tg of the prepared powders was assessed in triplicates using a differential scanning calorimeter (DSC) (Mettler, Switzerland) along with a cooling system (Admiral, East Brunswick, NJ, USA). Aluminum pans, which were completely airtight sealed, were utilized to prevent moisture loss while analyzing the samples. Briefly, 5 to $10 \mathrm{mg}$ of each sample (572, Kern \& Sohn GmbH, Balingen, Germany) were sealed in an aluminum pan and cooled to $-40{ }^{\circ} \mathrm{C}$. The temperature of the samples was kept constant for five minutes and then they were heated to achieve the target temperature of $150{ }^{\circ} \mathrm{C}$ at the constant heating rate of $10^{\circ} \mathrm{C} \cdot \mathrm{min}^{-1}$. The samples were then equilibrated at $150^{\circ} \mathrm{C}$ for five minutes and then cooled to $-40^{\circ} \mathrm{C}$ at the cooling rate of $10^{\circ} \mathrm{C} \cdot \mathrm{min}^{-1}$. Re-scans were immediately carried out to confirm the existence of the $\mathrm{Tg}$. A clean aluminum pan without any sample was used as the reference. The DSC thermograms were assessed for the enthalpy of melting and the onset, mid, and end of the transition [19].

\subsection{Color Evaluation}

Color values (L: Lightness; a: Redness-greenness; and b: Yellowness-blueness) of the date powders were analyzed using digital imaging and image analysis using the Photoshop software V.8 (Adobe Inc., Aurora, IL, USA) in the "Lab" mode [23,24]. Briefly, a digital DSC-W570 camera (Sony Corporation, Tokyo, Japan) was placed at a $0.3-\mathrm{m}$ distance from the powder surface in a white box $(0.5 \times 0.5 \times 0.6 \mathrm{~m})$ along with a $40 \mathrm{~W}$ fluorescent lamp. The angle between the sample surface and the lamp was $45^{\circ}$ while the angle between the axis of the camera lens and the sample surface was $90^{\circ}$. The digital photos were analyzed by Photoshop software to obtain the color parameters [24].

\subsection{Determination of Isotherms}

A range of $\mathrm{a}_{\mathrm{w}}$ from 0.095 to about 0.934 (at specified temperatures) was prepared using six supersaturated salt solutions. The water activity $\left(\mathrm{a}_{\mathrm{w}}\right)$ of these solutions at $60,40,25$, and $5{ }^{\circ} \mathrm{C}$ was obtained from the literature [25] (Table 1). Afterward, $2.0 \mathrm{~g}$ of each powder sample were weighed (572, Kern \& Sohn GmbH, Balingen, Germany) and put in hermetically sealed polyethylene vessels containing supersaturated salt solutions. These vessels were stored in laboratory ovens (805 General Electric, New York, NY, USA) at $60 \pm 0.1,40 \pm 0.1,25 \pm 0.1$, and $5 \pm 0.1{ }^{\circ} \mathrm{C}$. The sample weight was monitored using a digital milligram precision scale first on the third day of storage followed by one-day intervals measurement. This test was continued to the time that no change was observed in the weight of the samples, i.e., 5 to 15 days (depending on the temperature and the sample formulation). The equilibrium moisture of the powders was reported as the mass ratio of water molecules to dry solid. 
Table 1. The $\mathrm{a}_{\mathrm{w}}$ values of saturated salt solutions at various temperatures.

\begin{tabular}{lcccc}
\hline \multicolumn{1}{c}{$\begin{array}{c}\text { Type of Saturated Salt Solution } \\
\text { (IUPAC ID/Chemical Formula) }\end{array}$} & \multicolumn{4}{c}{ Temperature $\left({ }^{\circ} \mathbf{C}\right)$} \\
\cline { 2 - 4 } & $\mathbf{5}$ & $\mathbf{2 5}$ & $\mathbf{4 0}$ & $\mathbf{6 0}$ \\
\hline Lithium chloride $(\mathrm{LiCl})$ & 0.128 & 0.114 & 0.105 & 0.095 \\
Potassium acetate $\left(\mathrm{CH}_{3} \mathrm{COOK}\right)$ & 0.291 & 0.237 & 0.206 & 0.174 \\
Sodium iodide $(\mathrm{NaI})$ & 0.437 & 0.374 & 0.337 & 0.298 \\
Sodium nitrite $\left.(\mathrm{NaNO})_{2}\right)$ & 0.732 & 0.658 & 0.614 & 0.565 \\
Sodium chloride $(\mathrm{NaCl})$ & 0.805 & 0.761 & 0.734 & 0.702 \\
Potassium chloride $(\mathrm{KCl})$ & 0.934 & 0.855 & 0.806 & 0.751 \\
\hline
\end{tabular}

\subsection{Data Modeling}

Three well-known empirical models for correlating the relative humidity of the environment to the equilibrium moisture contents (EMCs) of samples, namely Brunauer-Emmett-Telle (BET), Guggenheim, Anderson, and de Boer (GAB), and Peleg models (Equations (3)-(5)), were used to fit the experimental data and determine the amount of monolayer water (monolayer moisture value) of the DS powders [19]. The water activity-EMC findings of all six water activity data points were employed for fitting to all models (i.e., GAB, Peleg, and BET). In this regard, the "Solver" function of the Microsoft Excel application (Microsoft Office, 2007, USA) was used [26] to minimize the residual sum of squares (RSS) between the experimental (exp) and predicted (pre) results. Several statistical parameters (Equations (6)-(9)), including the correlation coefficient $\left(R^{2}\right)$, standard error of estimate (SEE), mean relative percentage deviation modulus $\left(\mathrm{M}_{\mathrm{e}}\right)$, and RSS, were employed to assess the equations' suitability. The $\mathrm{R}^{2}$ was also calculated to estimate the proportion of variability correlated with each model. The SEE represents the precision of the experiment estimation. The equations that had the minimum values of SEE and RSS and the greatest value of $R^{2}$ were regarded as the most appropriate [27]. It was previously illustrated that $\mathrm{M}_{\mathrm{e}}$ values lower than $10 \%$ indicate an appropriate fit of the mathematical model to the experimental data [28]:

$$
\begin{gathered}
E M C=\frac{M_{0} \cdot C \cdot a_{w} \cdot K}{\left(1-K \cdot a_{w}\right)\left(1-K \cdot a_{w}+C \cdot K \cdot a_{w}\right)}, \\
\mathrm{EMC}=\frac{M_{0} \cdot C \cdot a_{w}}{\left(1-a_{w}\right)\left(1-C \cdot a_{w}-a_{w}\right)}, \\
E M C=k_{1} a_{w}^{n 1}+k_{2} a_{w}^{n 2},
\end{gathered}
$$

where $E M C$ and $M_{0}$ are the equilibrium and monolayer moisture contents (\% dry basis), respectively. " $a_{w}$ " is the water activity and $C, K, k_{1}, k_{2}, n_{1}$, and $n_{2}$ are model constants:

$$
\begin{gathered}
\text { RSS }=\sum_{i=1}^{n}(M i, \exp -M i, p r e)^{2}, \\
\text { SEE }=\sqrt{\sum_{i=1}^{n} \frac{(M i, \exp -M i, p r e)^{2}}{n}}, \\
\mathrm{M}_{\mathrm{e}}=\frac{100}{n} \sum_{i=1}^{n} \frac{|M i, \exp -M i, p r e|}{M i, \exp } .
\end{gathered}
$$

\subsection{Statistical Analysis}

All the tests were performed in triplicates and SPSS 16.0 (SPSS Inc., Chicago, IL, USA) was employed to analyze the data. Duncan's multiple range test $(p<0.05)$ was utilized to detect significant differences between the results. 


\section{Results and Discussion}

\subsection{Chemical Properties of the Date Syrup}

The chemical composition of the DS sample is presented in Table 2. According to the results, the concentrations of polysaccharides (glucose, fructose, and sucrose), protein, and fat in the studied DS were $74.5 \%, 0.8 \%$, and $0.1 \%$, respectively. In addition, the chemical analysis revealed that this DS has about 1\% sucrose (molecular weight of $342 \mathrm{~mol} / \mathrm{g}$ ), 30\% glucose (molecular weight of $180 \mathrm{~mol} / \mathrm{g}$ ), and $34 \%$ fructose (molecular weight of $180 \mathrm{~mol} / \mathrm{g}$ ). These carbohydrate molecules affect the $\mathrm{Tg}$ of food products [29]. Therefore, it is important to understand the concentration of these molecules in a product that is supposed to be dried. According to the literature, the total sugar content of DS may reach about $88 \%$, and fructose and glucose are the two main sugars molecules of this syrup [30]. Besides, DS contains some other elements, including minerals, metal ions, and vitamins, which can make it a nutritious food commodity. In the present study, the ash content of the DS was approximately $2 \%$, including non-fat, non-sugar, and non-protein components (Table 2). Similar to the DS, the AG used in the present study contained limited amounts of fat, protein, and ash $(2.5 \%, 0.14 \%$, and $3.11 \%$, respectively).

Table 2. Physicochemical properties of acacia gum and date syrup used in the present study.

\begin{tabular}{lcc}
\hline \multicolumn{1}{c}{ Component } & DS & AG \\
\hline Moisture content $(\% w / w)$ & $14.42 \pm 1.95^{\mathrm{a}}$ & $9.17 \pm 0.19^{\mathrm{b}}$ \\
Protein $(\% w / w)$ & $0.76 \pm 0.06^{\mathrm{b}}$ & $2.50 \pm 1.07^{\mathrm{a}}$ \\
Fat $(\% w / w)$ & $0.10 \pm 0.00^{\mathrm{a}}$ & $0.14 \pm 0.01^{\mathrm{a}}$ \\
Ash $(\% w / w)$ & $2.23 \pm 0.17^{\mathrm{b}}$ & $3.11 \pm 0.17^{\mathrm{a}}$ \\
Glucose $(\% w / w)$ & $39.63 \pm 0.08^{\mathrm{a}}$ & $\mathrm{NA}^{\mathrm{b}}$ \\
Fructose $(\% w / w)$ & $33.68 \pm 0.14^{\mathrm{a}}$ & $\mathrm{NA}^{\mathrm{b}}$ \\
Sucrose $(\% w / w)$ & $1.25 \pm 0.00^{\mathrm{a}}$ & $\mathrm{NA}^{\mathrm{b}}$ \\
${ }^{\circ}$ Bx & $82.00 \pm 0.05^{\mathrm{a}}$ & $\mathrm{NA}^{\mathrm{b}}$ \\
Total carbohydrates ${ }^{* *}(\% w / w)$ & $\sim 74.56$ & $\sim 85.08^{* *}$ \\
\hline
\end{tabular}

* Data are presented as the mean value of three replicates. Values with different superscripts in each row are significantly different $(p<0.05)$. NA: not applicable; DS: Date syrup; ${ }^{\circ} \mathrm{Bx}$ : degree of brix; Ag: acacia gum. ${ }^{* *}$ The total carbohydrate content of date syrup represents the summation of glucose, fructose and sucrose contents. This value for the acacia gum is based on the non-protein, non-ash and non-fat proportion of the gum, which mainly consists of D-galactose and L-arabinose according to the literature [13].

\subsection{Physical Properties of the Date Syrup Powders}

The preliminary results revealed that the production of DS powder without incorporation of AG was not feasible due to the high CD of the dehydrated DS samples. Physical properties of the DS powder samples (containing 30\%, 40\%, 50\%, and 60\% AG), including color values, $p_{\mathrm{b}}, \mathrm{CD}$, and $\mathrm{Tg}$, are presented in Table 3. According to the results, the $p_{\mathrm{b}}$ of the samples increased from 590 to 610 , 690 , and $730 \mathrm{~kg} \cdot \mathrm{m}^{-3}$ when the concentration of AG was increased from $30 \%$ to $40 \%, 50 \%$, and $60 \%$, respectively. This observation is related to the higher $p_{\mathrm{b}}$ of AG $\left(730 \mathrm{~kg} \cdot \mathrm{m}^{-3}\right)$ than that of the pure DS powder. These data indicate that the $p_{\mathrm{b}}$ of DS powders increased with the AG level. Moreover, the addition of AG to DS reduced the CD and hence can enhance the storage and handling ability of the resulting powder. The decreased CD could be correlated with the Tg. According to Table 3 , the Tg of the DS was $-1.27^{\circ} \mathrm{C}$, which indicates that this food commodity is expected to be at its rubbery state when stored at room temperature. As the AG has a higher $\operatorname{Tg}\left(84.73^{\circ} \mathrm{C}\right)$ than $\mathrm{DS}\left(-1.27^{\circ} \mathrm{C}\right)$, it acts as an anti-plasticizer component by increasing the $\mathrm{Tg}$ of the mixture. Therefore, the $\mathrm{Tg}$ of the syrup increased with increasing the AG concentration. The Tg values of the DS powders with $30 \%, 40 \%$, $50 \%$, and $60 \%$ AG levels were $10.2,17.4,28.2$, and $40.9^{\circ} \mathrm{C}$, respectively. Consequently, increasing the concentration of AG from $0 \%$ to $60 \%$ greatly decreased the CD from $54.82 \%$ to $0.08 \%$. 
Table 3. Glass transition temperature (Tg), caking degree (CD), color parameters ( $\mathrm{L}, \mathrm{a}$, and b), and density $\left(p_{\mathrm{b}}\right)$, of samples with various acacia gum concentrations. $0 \%$ AG: $100 \%$ DS-0\% AG; 30\% AG: 70\% DS-30\% AG); 40\% AG: 60\% DS-40\% acacia gum; 50\% AG: 50\% DS-50\% AG; 60\% AG: 40\% DS-60\% acacia gum; CD: caking degree; DS: date syrup; AG: acacia gum; Tg: glass transition; Tgi: onset; Tgm: mid-point; Tgc: endset.

\begin{tabular}{|c|c|c|c|c|c|c|c|c|}
\hline \multirow{2}{*}{ Sample } & \multirow{2}{*}{$\begin{array}{c}p_{\mathrm{b}} \\
\left(\mathrm{kg} \cdot \mathrm{m}^{-3}\right)\end{array}$} & \multicolumn{3}{|c|}{ Color Values * } & \multirow[b]{2}{*}{ CD (\%) } & \multirow[b]{2}{*}{ Tgi } & \multicolumn{2}{|c|}{$\operatorname{Tg}\left({ }^{\circ} \mathrm{C}\right)$} \\
\hline & & $\mathbf{L}$ & a & b & & & Tgm & Tgc \\
\hline $0 \%$ AG & - & $11.66 \pm 3.05^{c}$ & $7.33 \pm 0.57^{a}$ & $3.33 \pm 0.5^{f}$ & - & $-8.00 \pm 188^{f}$ & $-1.27 \pm 97^{f}$ & $5.19 \pm 2.16^{f}$ \\
\hline $30 \% \mathrm{AG}$ & $590 \pm 1^{c}$ & $64.33 \pm 0.57^{b}$ & $4.66 \pm 0.57^{a}$ & $47.66 \pm 1.52^{a}$ & $54.82 \pm 0.23^{\mathrm{a}}$ & $5.06 \pm 0.21 e^{e}$ & $10.22 \pm 0.16^{\mathrm{e}}$ & $15.73 \pm 0.33^{e}$ \\
\hline $50 \%$ AG & $690 \pm 0^{b}$ & $67.53 \pm 1.00^{\mathrm{a}}$ & $0.33 \pm 0.57^{b}$ & $42.33 \pm 0.57^{c}$ & $0.32 \pm 0.03^{c}$ & $14.84 \pm 0.06^{c}$ & $28.25 \pm 0.21^{c}$ & $41.29 \pm 0.34^{c}$ \\
\hline $60 \%$ AG & $730 \pm 3^{a}$ & $67.66 \pm 1.15^{\mathrm{a}}$ & $0.66 \pm 0.57^{b}$ & $36.33 \pm 0.57^{\mathrm{d}}$ & $0.08 \pm 0.00^{\mathrm{d}}$ & $28.09 \pm 0.82^{b}$ & $40.87 \pm 0.58^{b}$ & $52.88 \pm 0.26^{b}$ \\
\hline AG & $730 \pm 1^{a}$ & $68.33 \pm 0.57^{a}$ & $-9.00 \pm 0.00^{c}$ & $17.33 \pm 0.57^{\mathrm{e}}$ & $0.00 \pm 0.00^{\mathrm{d}}$ & $76.90 \pm 0.93^{a}$ & $84.73 \pm 1.89^{a}$ & $91.47 \pm 1.72^{a}$ \\
\hline
\end{tabular}

* The presented data are the mean value of 3 replicates \pm standard deviations. Values with different superscripts in each column are significantly different $(p<0.05)$.

\subsection{Sorption Isotherms}

The EMC of samples at the studied temperatures are shown in Table 4. The EMC of AG-containing samples (DS-AG) was less than that of DS at similar $\mathrm{a}_{\mathrm{w}}$ values. This observation could be related to the ability of AG in reducing the hygroscopic properties of mixtures [31]. The incorporation of this hydrocolloid in DS changed the hydrophilic-hydrophobic balance and affected the amount of adsorbed $\mathrm{H}_{2} \mathrm{O}$ molecules. Furthermore, the water sorption phenomenon can be related to the swelling-caused changes in the polymer structural [32]. According to the literature, the stability of AG-containing systems might be correlated with the $\mathrm{a}_{\mathrm{w}}$ and $\mathrm{Tg}$, which were affected by gum incorporation [33]. Therefore, the samples were sticky at temperatures above Tg and non-sticky at temperatures below $\mathrm{Tg}$. Likewise, a study on the impacts of AG on $\mathrm{Tg}$ of strawberry pulp powder showed that increasing the hydrocolloid concentration enhanced the Tg of the mixture [12]. It also showed that the EMC of AG-containing samples was lower than the samples that were free from the gum. A similar observation was made for a dried mixture of pineapple syrup and AG [31]. Furthermore, researchers confirmed that enhancing the moisture content (from $0 \%$ to $30 \%$ ) reduced the Tg of lyophilized pineapple pulp whereas the addition of AG minimized this highly plasticizing effect of water [31].

Table 4. Equilibrium moisture content (EMC) of the studied samples at various temperatures. 0\% AG: 100\% DS-0\% AG; 30\% AG: 70\% DS-30\% AG; 40\% AG: 60\% DS-40\% acacia gum; 50\% AG: 50\% DS-50\% AG; $60 \%$ AG: $40 \%$ DS-60\% acacia gum; DS: date syrup; AG: acacia gum.

\begin{tabular}{|c|c|c|c|c|c|c|}
\hline \multirow{2}{*}{$\begin{array}{c}\text { Temperature } \\
\left({ }^{\circ} \mathrm{C}\right)\end{array}$} & \multirow[t]{2}{*}{$a_{w}$} & \multicolumn{5}{|c|}{ EMC of Samples (g Water/g Dry Matter) } \\
\hline & & $0 \%$ AG & $30 \%$ AG & $40 \%$ AG & $50 \%$ AG & $60 \%$ AG \\
\hline \multirow{6}{*}{5} & 0.128 & $0.127 \pm 0.001$ & $0.031 \pm 0.002$ & $0.022 \pm 0.001$ & $0.025 \pm 0.002$ & $0.023 \pm 0.000$ \\
\hline & 0.291 & $0.136 \pm 0.003$ & $0.045 \pm 0.000$ & $0.040 \pm 0.000$ & $0.037 \pm 0.002$ & $0.040 \pm 0.002$ \\
\hline & 0.437 & $0.192 \pm 0.004$ & $0.098 \pm 0.000$ & $0.093 \pm 0.001$ & $0.077 \pm 0.002$ & $0.076 \pm 0.000$ \\
\hline & 0.732 & $0.353 \pm 0.005$ & $0.242 \pm 0.015$ & $0.228 \pm 0.003$ & $0.217 \pm 0.009$ & $0.220 \pm 0.001$ \\
\hline & 0.805 & $0.402 \pm 0.005$ & $0.372 \pm 0.010$ & $0.337 \pm 0.006$ & $0.312 \pm 0.009$ & $0.310 \pm 0.001$ \\
\hline & 0.934 & $0.828 \pm 0.016$ & $0.566 \pm 0.009$ & $0.560 \pm 0.008$ & $0.516 \pm 0.003$ & $0.502 \pm 0.012$ \\
\hline \multirow{6}{*}{25} & 0.114 & $0.092 \pm 0.006$ & $0.023 \pm 0.001$ & $0.022 \pm 0.003$ & $0.021 \pm 0.000$ & $0.027 \pm 0.00$ \\
\hline & 0.237 & $0.117 \pm 0.011$ & $0.037 \pm 0.001$ & $0.040 \pm 0.000$ & $0.031 \pm 0.001$ & $0.034 \pm 0.002$ \\
\hline & 0.374 & $0.155 \pm 0.004$ & $0.081 \pm 0.001$ & $0.077 \pm 0.001$ & $0.078 \pm 0.000$ & $0.073 \pm 0.001$ \\
\hline & 0.658 & $0.305 \pm 0.011$ & $0.209 \pm 0.007$ & $0.203 \pm 0.002$ & $0.188 \pm 0.004$ & $0.190 \pm 0.002$ \\
\hline & 0.761 & $0.384 \pm 0.005$ & $0.308 \pm 0.002$ & $0.281 \pm 0.002$ & $0.267 \pm 0.004$ & $0.273 \pm 0.002$ \\
\hline & 0.855 & $0.670 \pm 0.010$ & $0.516 \pm 0.004$ & $0.469 \pm 0.008$ & $0.429 \pm 0.010$ & $0.436 \pm 0.008$ \\
\hline \multirow{6}{*}{40} & 0.105 & $0.049 \pm 0.003$ & $0.022 \pm 0.001$ & $0.016 \pm 0.001$ & $0.014 \pm 0.004$ & $0.021 \pm 0.001$ \\
\hline & 0.206 & $0.052 \pm 0.001$ & $0.039 \pm 0.000$ & $0.030 \pm 0.004$ & $0.026 \pm 0.001$ & $0.031 \pm 0.002$ \\
\hline & 0.337 & $0.062 \pm 0.001$ & $0.056 \pm 0.000$ & $0.0584 \pm 0.001$ & $0.054 \pm 0.004$ & $0.054 \pm 0.001$ \\
\hline & 0.614 & $0.280 \pm 0.006$ & $0.234 \pm 0.003$ & $0.179 \pm 0.002$ & $0.163 \pm 0.007$ & $0.188 \pm 0.002$ \\
\hline & 0.734 & $0.360 \pm 0.006$ & $0.293 \pm 0.004$ & $0.275 \pm 0.003$ & $0.255 \pm 0.002$ & $0.234 \pm 0.004$ \\
\hline & 0.806 & $0.655 \pm 0.008$ & $0.577 \pm 0.012$ & $0.537 \pm 0.009$ & $0.513 \pm 0.003$ & $0.428 \pm 0.005$ \\
\hline \multirow{6}{*}{60} & 0.095 & $0.026 \pm 0.000$ & $0.021 \pm 0.001$ & $0.010 \pm 0.001$ & $0.011 \pm 0.000$ & $0.012 \pm 0.001$ \\
\hline & 0.174 & $0.044 \pm 0.005$ & $0.034 \pm 0.000$ & $0.032 \pm 0.001$ & $0.018 \pm 0.001$ & $0.026 \pm 0.004$ \\
\hline & 0.298 & $0.056 \pm 0.003$ & $0.047 \pm 0.002$ & $0.037 \pm 0.001$ & $0.037 \pm 0.000$ & $0.0384 \pm 0.001$ \\
\hline & 0.565 & $0.202 \pm 0.004$ & $0.186 \pm 0.004$ & $0.166 \pm 0.005$ & $0.161 \pm 0.000$ & $0.132 \pm 0.001$ \\
\hline & 0.702 & $0.304 \pm 0.006$ & $0.193 \pm 0.002$ & $0.199 \pm 0.008$ & $0.185 \pm 0.002$ & $0.191 \pm 0.008$ \\
\hline & 0.751 & $0.502 \pm 0.003$ & $0.409 \pm 0.011$ & $0.408 \pm 0.004$ & $0.356 \pm 0.005$ & $0.355 \pm 0.005$ \\
\hline
\end{tabular}


The data presented in Table 4 illustrates that the EMC of samples was reduced by an increase in the temperature $\left(5-60^{\circ} \mathrm{C}\right)$. Similar results were reported previously for cowpea and fig samples [34,35]. At elevated temperatures, intermolecular forces of attraction diminish because of the increased kinetic energy of molecules, resulting in increased molecular mobility. For that reason, $\mathrm{H}_{2} \mathrm{O}$ molecules, which have limited motions, are expected to form stronger bonds with the binding sites of polymer molecules when the temperature is low [35]. Figures 1-4 represent the sorption isotherms obtained from the experimental data at different temperatures along with graphs acquired from the studied mathematical models. Generally, all isotherms showed a slight increase and a sharp increase in the EMC at the low ranges of $\mathrm{a}_{\mathrm{w}}$ and at the intermediate ranges of $\mathrm{a}_{\mathrm{w}}(\sim 0.5)$, respectively. This trend was comparable to a common pattern that was previously reported for food materials with a high sugar content $[19,36]$. This is because of the principal influence of solvent-solute interactions on the dissolution of sugar molecules [12]. In addition, the isotherm of the DS-AG powder was significantly different from that of DS. This observation was in line with those reported for some fruit samples in the literature [12,31]. According to the results, all the experimental isotherms in the present study are similar to that of the type III isotherm based on the classification of Brunauer [31].

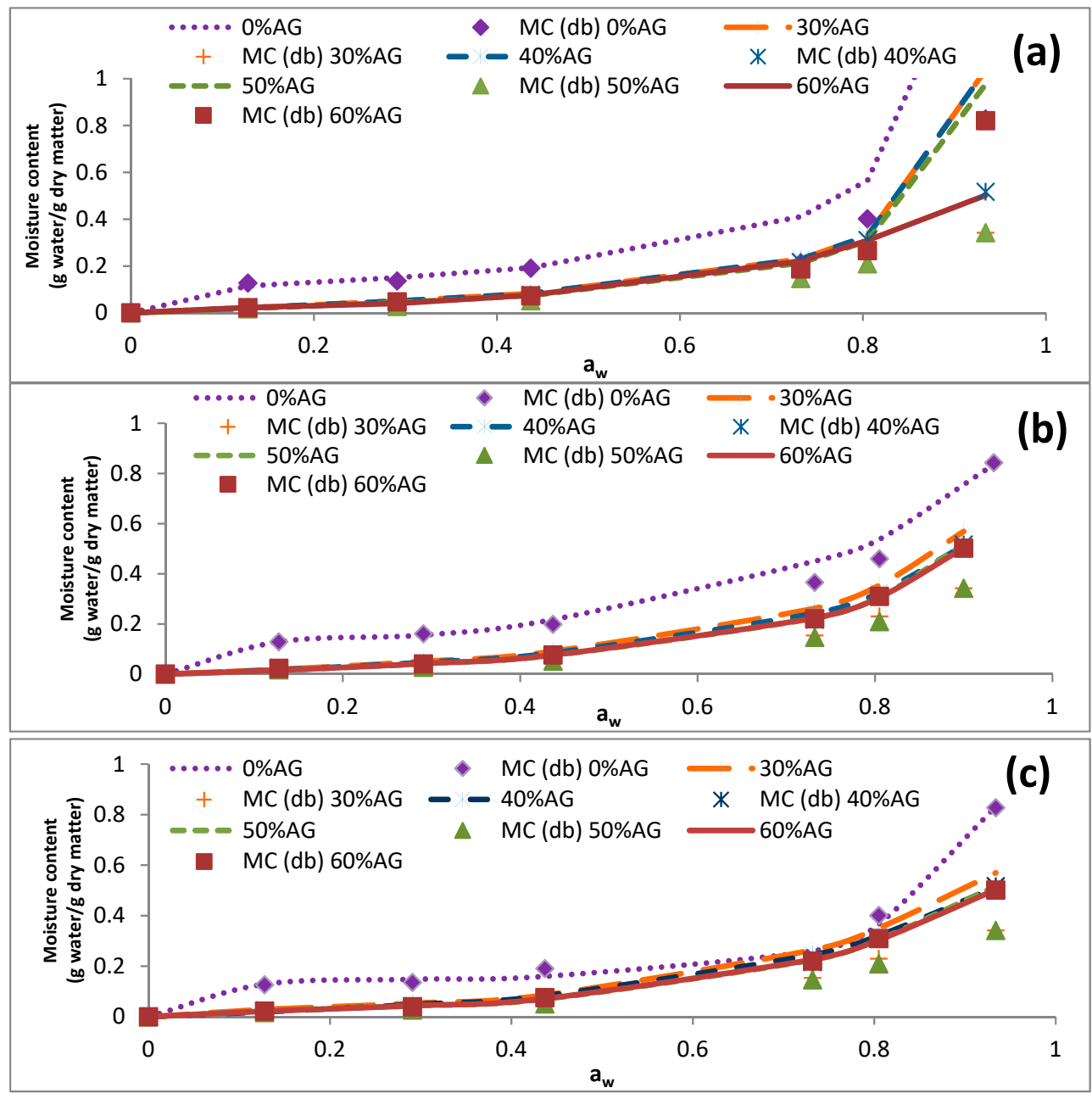

Figure 1. Effects of acacia gum concentration on the equilibrium moisture sorption isotherm of date syrup powders at $5{ }^{\circ} \mathrm{C}$. The experimental data are presented as symbols and the data obtained by fitting the experimental data into mathematical models are presented as lines. $(\mathbf{a}-\mathbf{c})$ represent the obtained data from BET, GAB, and Peleg models. 0\% AG: 100\% DS-0\% AG; 30\% AG: 70\% DS-30\% AG; 40\% AG: $60 \%$ DS- $40 \%$ acacia gum; $50 \%$ AG: $50 \%$ DS-50\% AG; $60 \%$ AG: $40 \%$ DS-60\% acacia gum; DS: date syrup; AG: acacia gum. 


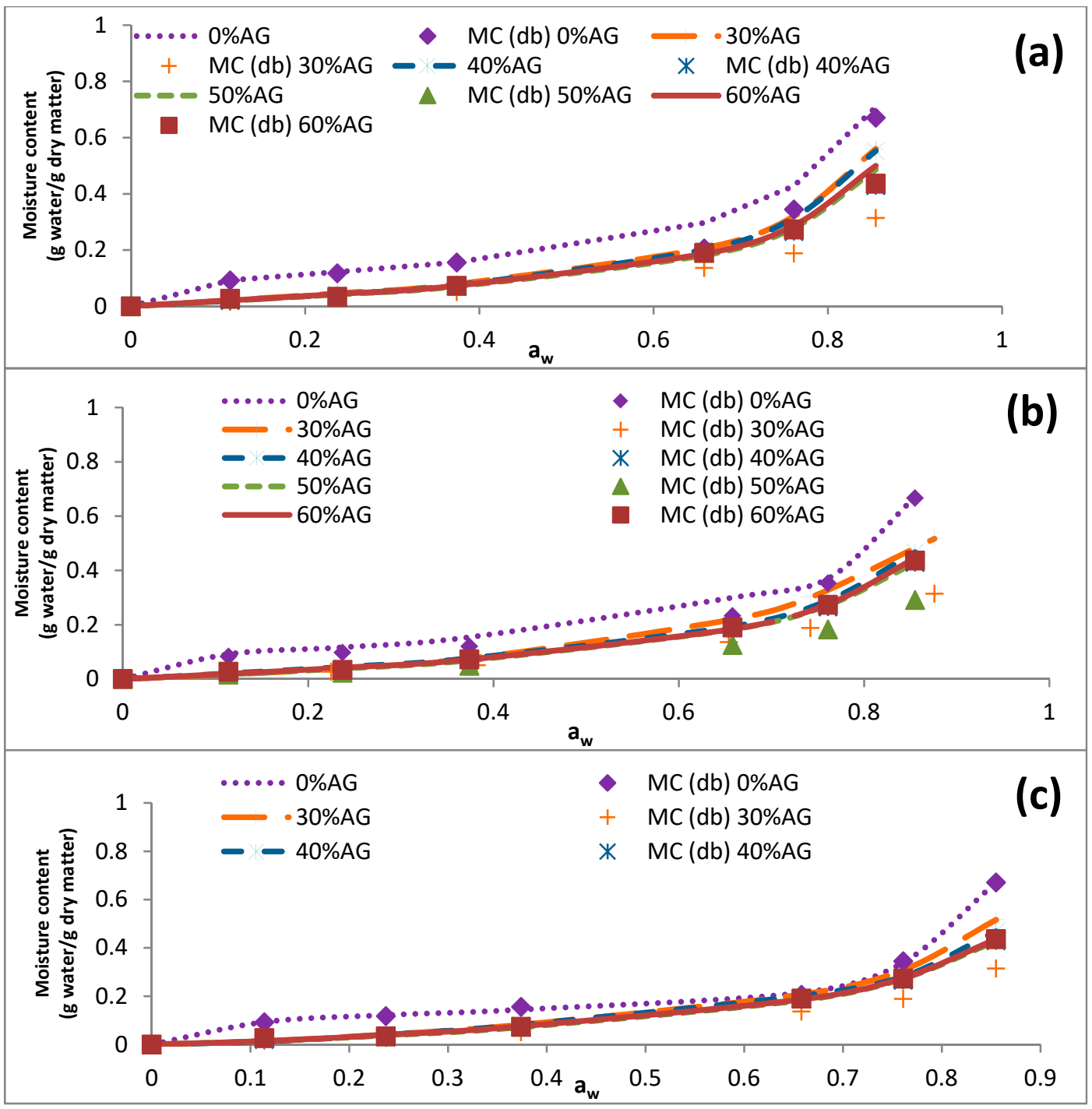

Figure 2. Effects of acacia gum concentration on the equilibrium moisture sorption isotherm of date syrup powders at $25^{\circ} \mathrm{C}$. The experimental data are presented as symbols and the data obtained by fitting the experimental data into mathematical models are presented as lines. (a-c) represent the obtained data from BET, GAB, and Peleg models. 0\% AG: 100\% DS-0\% AG; 30\% AG: 70\% DS-30\% AG; 40\% AG: 60\% DS-40\% acacia gum; 50\% AG: 50\% DS-50\% AG; 60\% AG: 40\% DS-60\% acacia gum; DS: date syrup; AG: acacia gum. 


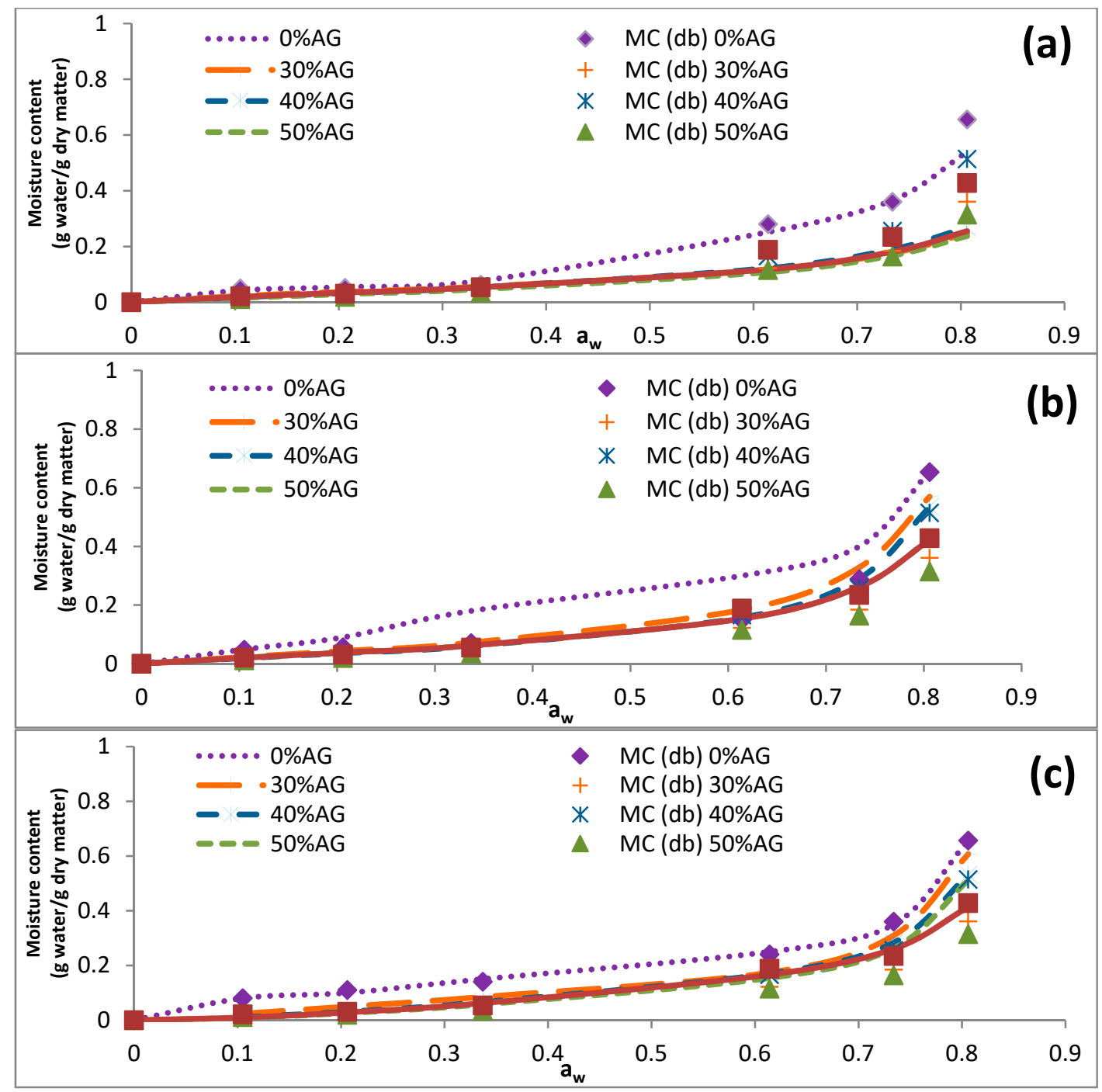

Figure 3. Effects of acacia gum concentration on the equilibrium moisture sorption isotherm of date syrup powders at $40^{\circ} \mathrm{C}$. The experimental data are presented as symbols and the data obtained by fitting experimental data into mathematical models are presented as lines. (a-c) represent the obtained data from BET, GAB, and Peleg models. 0\% AG: 100\% DS-0\% AG; 30\% AG: 70\% DS-30\% AG; 40\% AG: 60\% DS- $40 \%$ acacia gum; 50\% AG: 50\% DS-50\% AG; 60\% AG: $40 \%$ DS-60\% acacia gum; DS: date syrup; AG: acacia gum. 


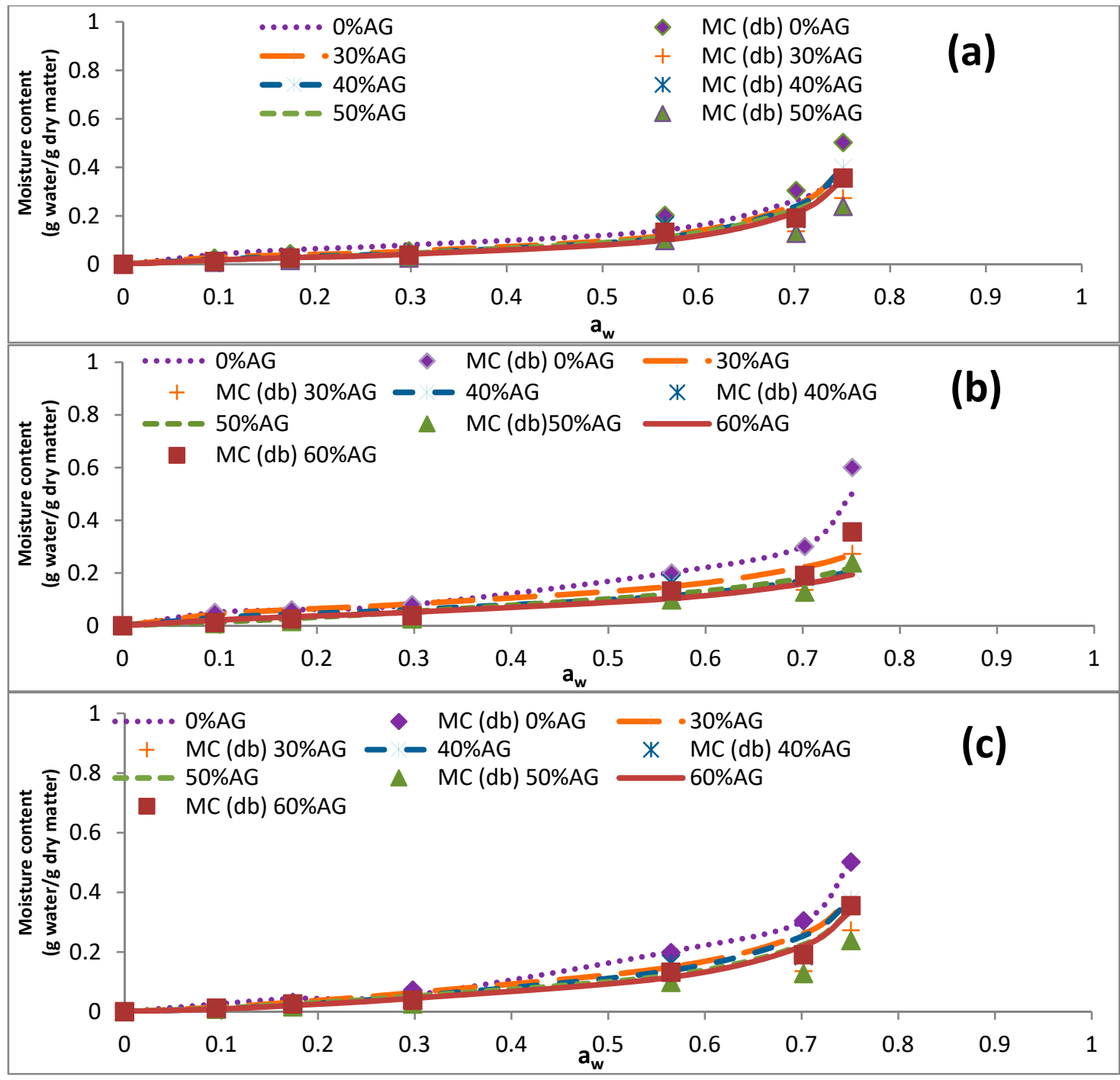

Figure 4. The effect of acacia gum concentration on the equilibrium moisture sorption isotherm of date syrup powders at $60{ }^{\circ} \mathrm{C}$. The experimental data are presented as symbols and the data obtained by fitting the experimental data into mathematical models are presented as lines. $(\mathbf{a}-\mathbf{c})$ represent the obtained data from BET, GAB and Peleg models. 0\% AG: 100\% DS-0\% AG; 30\% AG: 70\% DS-30\% AG; 40\% AG: 60\% DS-40\% acacia gum; 50\% AG: 50\% DS-50\% AG; 60\% AG: 40\% DS-60\% acacia gum; DS: date syrup; AG: acacia gum.

The results showed that the anti-plasticizing effect of AG was different from those of maltodextrin for date powder production [19]. For example, at $5{ }^{\circ} \mathrm{C}$ (the $\mathrm{a}_{\mathrm{w}}$ of 0.128 ), the EMC of samples was changed from 0.1269 to 0.0230 and 0.02113 when $60 \%$ of AG and maltodextrin was used in the formulation, respectively. In other words, incorporation of $60 \%$ AG and maltodextrin resulted in an $82 \%$ and $83 \%$ decrease in EMC (Table 4). Similarly, at $60{ }^{\circ} \mathrm{C}\left(\mathrm{a}_{\mathrm{w}}\right.$ of 0.095$)$, the EMC of the sample was changed from 0.0256 to 0.0116 and 0.0135 when $60 \%$ of AG and maltodextrin was used in the formulation, respectively; that is to say, incorporation of $60 \% \mathrm{AG}$ and maltodextrin resulted in a $55 \%$ and $47 \%$ decrease in EMC of the samples, respectively. Indeed, the differences between the anti-plasticizing effects of these natural anti-plasticizers were more profound at higher temperatures. According to the data reported in the present study and a previous effort on date powder production [19], it can be highlighted that both AG and maltodextrin can be used as effective anti-plasticizers while the variations in the intensity of their effects suggest a need for an optimization study, in terms of concentration and type of anti-plasticizer, before commercial production of date syrup powder. 


\subsection{Data Modeling}

The estimated constants of the studied equations, i.e., GAB, BET, and Peleg, are presented in Table 5 .

Table 5. The calculated constants for the studied mathematical models (Peleg, GAB, and BET) and the corresponding monolayer moisture levels $\left(\mathrm{M}_{0}\right)$ for the evaluated samples at various temperatures. 0\% AG: 100\% DS-0\% AG; 30\% AG: 70\% DS-30\% AG; 40\% AG: 60\% DS-40\% acacia gum; 50\% AG: 50\% DS-50\% AG; 60\% AG: 40\% DS-60\% acacia gum; DS: date syrup; AG: acacia gum; $\mathrm{M}_{0}$ : monolayer moisture content; $\mathrm{C}, \mathrm{K}, \mathrm{k}_{1}, \mathrm{k}_{2}, \mathrm{n}_{1}$ and $\mathrm{n}_{2}$ : model constants.

\begin{tabular}{lcccccccccc}
\hline \multicolumn{1}{c}{ Samples } & Temperature $\left({ }^{\circ} \mathbf{C}\right)$ & \multicolumn{2}{c}{ BET } & \multicolumn{3}{c}{ GAB } & \multicolumn{4}{c}{ Peleg } \\
\hline & & $\mathbf{M}_{\mathbf{0}} \mathbf{( \% )}$ & $\mathbf{C}$ & $\mathbf{M}_{\mathbf{0}} \mathbf{( \% )}$ & $\mathbf{C}$ & $\mathbf{K}$ & $\mathbf{k}_{\mathbf{1}}$ & $\mathbf{k}_{\mathbf{2}}$ & $\mathbf{n}_{\mathbf{1}}$ & $\mathbf{n}_{\mathbf{2}}$ \\
\hline $0 \%$ AG & 5 & 11.1 & 53.1 & 37.54 & 0.29 & 0.82 & 1.14 & 0.18 & 8.26 & 0.16 \\
$30 \%$ AG & 5 & 7.16 & 3.23 & 13.32 & 1.13 & 0.89 & 0.6 & 0.11 & 4.04 & 0.67 \\
$40 \%$ AG & 5 & 7.01 & 2.70 & 12.92 & 1.07 & 0.88 & 0.39 & 1.64 & 3.1 & 0.95 \\
$50 \%$ AG & 5 & 6.74 & 2.22 & 10.19 & 1.16 & 0.92 & 0.56 & 0.1 & 4.39 & 0.71 \\
$60 \%$ AG & 5 & 6.61 & 1.69 & 10.85 & 1.12 & 0.91 & 0.53 & 0.1 & 4.23 & 0.76 \\
$0 \%$ AG & 25 & 10.25 & 28.89 & 18.42 & 0.6 & 0.93 & 2.21 & 0.2 & 9.79 & 0.36 \\
$30 \%$ AG & 25 & 7.54 & 2.75 & 9.62 & 1.84 & 0.97 & 1.22 & 0.35 & 10.5 & 1.48 \\
$40 \%$ AG & 25 & 6.89 & 3.31 & 9.04 & 2.1 & 0.96 & 1.53 & 0.37 & 13.82 & 1.55 \\
$50 \%$ AG & 25 & 6.18 & 1.99 & 9.66 & 1.59 & 0.94 & 1.00 & 0.33 & 11.39 & 1.55 \\
$60 \%$ AG & 25 & 6.15 & 3.81 & 9.43 & 1.79 & 0.94 & 0.77 & 0.28 & 8.44 & 1.36 \\
$0 \%$ AG & 40 & 9.27 & 2.34 & 8.80 & 0.52 & 1.1 & 7.42 & 0.28 & 13.45 & 1.19 \\
$30 \%$ AG & 40 & 5.12 & 5.47 & 6.89 & 3.25 & 1.96 & 6.9 & 0.27 & 13.41 & 1.05 \\
$40 \%$ AG & 40 & 5.65 & 3.60 & 5.70 & 3.22 & 1.11 & 6.61 & 0.22 & 13.37 & 1.04 \\
$50 \%$ AG & 40 & 5.25 & 3.44 & 5.07 & 3.29 & 1.12 & 6.01 & 0.23 & 13.35 & 1.21 \\
$60 \%$ AG & 40 & 5.08 & 4.29 & 6.11 & 3.25 & 1.06 & 3.2 & 0.32 & 13.45 & 1.46 \\
$0 \%$ AG & 60 & 6.1 & 3.23 & 6.49 & 2.54 & 1.11 & 8.9 & 0.26 & 13.38 & 1.2 \\
$30 \%$ AG & 60 & 4.21 & 8.13 & 4.06 & 11.78 & 1.19 & 7.89 & 0.29 & 13.43 & 1.26 \\
$40 \%$ AG & 60 & 3.93 & 5.43 & 3.86 & 5.5 & 1.15 & 7.93 & 0.31 & 13.41 & 1.49 \\
$50 \%$ AG & 60 & 4.80 & 2.50 & 4.18 & 4.33 & 1.17 & 7.8 & 0.25 & 13.42 & 1.32 \\
$60 \%$ AG & 60 & 4.82 & 3.64 & 3.46 & 6.7 & 1.2 & 7.85 & 0.25 & 13.41 & 1.4 \\
\hline
\end{tabular}

Besides, the criteria for considering a mathematical equation as an appropriate model, including $\mathrm{R}^{2}$, RSS, SEE, and Me, are illustrated in Table 6 . The greatest $\mathrm{R}^{2}$ values and the minimum RSS, SEE, and $\mathrm{M}_{\mathrm{e}}$ values can be regarded as a sign of better correlations between the experimental and calculated data. According to the above-described criteria, GAB and Peleg models $\left(R^{2}>0.98\right)$ are suitable for the prediction of EMC of DS and DS-AG samples. According to the presented data in Table 6, the average $M_{e}$ values of the Peleg and GAB model are considerably (about $90 \%$ ) smaller than that of the BET model, which indicates that the experimental data can be satisfyingly fitted into these models. 
Table 6. The coefficient of determination $\left(\mathrm{R}^{2}\right)$, residual sum of squares (RSS), standard error of estimate (SEE), and the mean relative percentage deviation moduli (Me) for the models applied to the experimental data of the studied sample at various temperatures. 0\% AG: 100\% DS-0\% AG; 30\% AG: 70\% DS-30\% AG; 40\% AG: 60\% DS- $40 \%$ acacia gum; $50 \%$ AG: $50 \%$ DS-50\% AG; $60 \%$ AG: $40 \%$ DS-60\% acacia gum; DS: date syrup; AG: acacia gum.

\begin{tabular}{|c|c|c|c|c|c|c|c|c|c|c|c|c|c|c|c|c|c|c|}
\hline & \multirow[b]{2}{*}{ Temperature $\left({ }^{\circ} \mathrm{C}\right)$} & \multicolumn{4}{|c|}{ RSS } & \multicolumn{4}{|c|}{ SEE } & \multicolumn{5}{|c|}{ Me (\%) } & \multicolumn{4}{|c|}{$\mathbf{R}^{2}$} \\
\hline & & 5 & 25 & 40 & 60 & 5 & 25 & 40 & 60 & 5 & 25 & 40 & 60 & Overall\% & $\% 5$ & 25 & 40 & 60 \\
\hline Sample & Models & & & & & & & & & & & & & & & & & \\
\hline \multirow{3}{*}{$\begin{array}{l}0 \% \\
\mathrm{AG}\end{array}$} & BET & $3.46 \times 10^{-2}$ & $3.02 \times 10^{-2}$ & $1.29 \times 10^{-2}$ & $5.08 \times 10^{-2}$ & 0.07030 & 0.02070 & 0.04280 & 0.02430 & 15.80 & 11.10 & 17.23 & 17.37 & 15.38 & 0.971 & 0.980 & 0.955 & 0.973 \\
\hline & GAB & $1.46 \times 10^{-2}$ & $2.47 \times 10^{-3}$ & $1.36 \times 10^{-3}$ & $7.08 \times 10^{-5}$ & 0.04570 & 0.01877 & 0.01401 & 0.00318 & 8.66 & 9.22 & 7.00 & 8.97 & 8.46 & 0.988 & 0.992 & 0.995 & 0.999 \\
\hline & Peleg & $4.59 \times 10^{-3}$ & $2.50 \times 10^{-4}$ & $1.33 \times 10^{-3}$ & $4.08 \times 10^{-5}$ & 0.02559 & 0.00597 & 0.01375 & 0.00241 & 7.31 & 8.63 & 7.75 & 8.60 & 8.07 & 0.989 & 0.999 & 0.995 & 0.999 \\
\hline \multirow{3}{*}{$\begin{array}{c}30 \% \\
\mathrm{AG}\end{array}$} & BET & $5.00 \times 10^{-3}$ & $1.00 \times 10^{-3}$ & $5.92 \times 10^{-3}$ & $3.30 \times 10^{-2}$ & 0.0850 & 0.03820 & 0.02910 & 0.02910 & 18.27 & 17.25 & 18.79 & 14.60 & 17.23 & 0.980 & 0.975 & 0.962 & 0.983 \\
\hline & GAB & $9.55 \times 10^{-4}$ & $1.80 \times 10^{-4}$ & $4.11 \times 10^{-3}$ & $7.78 \times 10^{-3}$ & 0.01168 & 0.00506 & 0.02423 & 0.00333 & 10.22 & 5.89 & 7.83 & 8.16 & 8.03 & 0.996 & 0.999 & 0.984 & 0.997 \\
\hline & Peleg & $1.17 \times 10^{-4}$ & $1.16 \times 10^{-4}$ & $3.69 \times 10^{-3}$ & $7.23 \times 10^{-3}$ & 0.01292 & 0.00406 & 0.02350 & 0.00320 & 7.56 & 7.95 & 7.59 & 8.80 & 7.98 & 0.995 & 0.999 & 0.980 & 0.996 \\
\hline \multirow{3}{*}{$\begin{array}{l}40 \% \\
\mathrm{AG}\end{array}$} & BET & $2.31 \times 10^{-3}$ & $2.03 \times 10^{-3}$ & $4.00 \times 10^{-3}$ & $3.50 \times 10^{-3}$ & 0.05550 & 0.01890 & 0.07801 & 0.02240 & 19.23 & 15.19 & 16.78 & 14.10 & 16.33 & 0.969 & 0.970 & 0.968 & 0.909 \\
\hline & GAB & $5.05 \times 10^{-4}$ & $1.96 \times 10^{-4}$ & $7.44 \times 10^{-4}$ & $5.33 \times 10^{-3}$ & 0.00849 & 0.00528 & 0.00103 & 0.00270 & 8.06 & 8.76 & 8.61 & 9.84 & 8.82 & 0.997 & 0.998 & 0.996 & 0.996 \\
\hline & Peleg & $4.36 \times 10^{-4}$ & $1.07 \times 10^{-4}$ & $2.49 \times 10^{-4}$ & $5.27 \times 10^{-3}$ & 0.00102 & 0.00390 & 0.00596 & 0.00274 & 7.51 & 7.06 & 7.82 & 8.46 & 7.71 & 0.998 & 0.999 & 0.998 & 0.998 \\
\hline \multirow{3}{*}{$\begin{array}{c}50 \% \\
\mathrm{AG}\end{array}$} & BET & $1.22 \times 10^{-3}$ & $9.34 \times 10^{-3}$ & $1.00 \times 10^{-3}$ & $3.00 \times 10^{-3}$ & 0.03820 & 0.03732 & 0.04410 & 0.07002 & 19.25 & 18.10 & 19.11 & 19.69 & 19.04 & 0.972 & 0.980 & 0.970 & 0.967 \\
\hline & GAB & $2.35 \times 10^{-4}$ & $1.28 \times 10^{-4}$ & $8.78 \times 10^{-4}$ & $4.55 \times 10^{-4}$ & 0.00579 & 0.00427 & 0.03526 & 0.02548 & 8.60 & 6.95 & 8.29 & 6.08 & 7.48 & 0.999 & 0.999 & 0.986 & 0.980 \\
\hline & Peleg & $2.00 \times 10^{-4}$ & $8.14 \times 10^{-5}$ & $1.95 \times 10^{-4}$ & $3.61 \times 10^{-4}$ & 0.00535 & 0.00341 & 0.00527 & 0.02271 & 5.84 & 7.43 & 7.86 & 5.83 & 6.74 & 0.999 & 0.999 & 0.999 & 0.997 \\
\hline \multirow{3}{*}{$\begin{array}{l}60 \% \\
\mathrm{AG}\end{array}$} & BET & $5.47 \times 10^{-3}$ & $1.40 \times 10^{-3}$ & $1.22 \times 10^{-3}$ & $1.00 \times 10^{-3}$ & 0.02713 & 0.04522 & 0.01401 & 0.0121 & 19.00 & 18.16 & 18.10 & 21.57 & 19.21 & 0.985 & 0.970 & 0.970 & 0.970 \\
\hline & GAB & $8.44 \times 10^{-5}$ & $1.82 \times 10^{-4}$ & $2.12 \times 10^{-4}$ & $1.68 \times 10^{-4}$ & 0.0034 & 0.00510 & 0.00738 & 0.00551 & 5.66 & 8.89 & 8.33 & 8.29 & 7.79 & 0.999 & 0.998 & 0.985 & 0.983 \\
\hline & Peleg & $9.90 \times 10^{-5}$ & $2.16 \times 10^{-4}$ & $1.61 \times 10^{-4}$ & $1.58 \times 10^{-4}$ & 0.00377 & 0.00555 & 0.00151 & 0.00150 & 3.32 & 2.11 & 4.80 & 3.28 & 3.38 & 0.999 & 0.998 & 0.989 & 0.984 \\
\hline
\end{tabular}


The GAB model yielded average $\mathrm{M}_{\mathrm{e}}$ values of $8.46 \%$ (ranging from $7.00 \%$ to $9.22 \%$ ), $8.03 \%$ (ranging from $5.89 \%$ to $10.22 \%$ ), $8.82 \%$ (ranging from $8.06 \%$ to $9.84 \%$ ), $7.48 \%$ (ranging from $6.08 \%$ to 8.60 ), and $7.79 \%$ (ranging from $5.66 \%$ to $8.89 \%$ ) for DS powders containing $0 \%$ (control sample), $30 \%, 40 \%, 50 \%$, and $60 \%$ AG, respectively. Furthermore, Peleg models yielded average $\mathrm{M}_{\mathrm{e}}$ values of $8.07 \%, 7.98 \%, 7.71 \%, 6.74 \%$, and $3.8 \%$ for DS powders containing $0 \%, 30 \%, 40 \%, 50 \%$, and $60 \%$ AG, respectively. Moreover, average $\mathrm{M}_{\mathrm{e}}$ values of $15.38 \%, 17.23 \%, 16.33 \%, 19.04 \%$, and $19.21 \%$ were obtained from the BET model for DS powders containing $0 \%, 30 \%, 40 \%, 50 \%$, and $60 \%$ AG, respectively. These findings were in agreement with that documented by Aviara et al. (2006), who mentioned that only relying on RSS and SEE is an inappropriate approach to determine the suitability of a model for fitting experimental moisture sorption isotherms [37]. It seems that the GAB and Peleg equations gave the most appropriate fit for the sorption isotherms of the studied samples with a wide range of $\mathrm{a}_{\mathrm{w}}$ according to the SEE, RSS $\mathrm{R}^{2}$, and $\mathrm{M}_{\mathrm{e}}$ values (Table 6). This also indicates that the BET model was not able to describe the water activity-EMC well in DS powder, indicating the phenomena of dissolution may predominate over sorption. Therefore, concentrations of the monolayer water $\left(\mathrm{M}_{0}\right)$ at various temperatures were obtained through these two models. The $\mathrm{M}_{0}$ values of the DS samples were higher than those of the AG-containing samples. Higher concentrations of AG resulted in smaller amounts of $\mathrm{M}_{0}$. This was the case for both the GAB and BET models at all the studied temperatures. AG has the role of an effective anti-plasticizer in the present study. This anti-plasticizer has a larger size and a higher molecular weight than small sugar molecules of DS. These characteristics of AG can decrease the monolayer water level by reducing the overall ratio of interaction sites.

According to the results, $\mathrm{M}_{0}$ values of the control (DS) at 5 to $60{ }^{\circ} \mathrm{C}$ varied from 0.06 to 0.11 and from 0.06 to 0.37 (g water/g dry solids) for the BET and GAB models, respectively. Likewise, a previously conducted study calculated 0.06 to 0.17 (g water/g dry solids) for $\mathrm{M}_{0}$ values of date paste at 5 to $40{ }^{\circ} \mathrm{C}$ [38]. The results of the current study revealed that the $\mathrm{M}_{0}$ value was reduced by an increase in the temperature (from 5 to $60^{\circ} \mathrm{C}$ ). A similar observation was reported for fig, pineapple, and DS $[31,35,38]$. The reduction of $\mathrm{M}_{0}$ may be illustrated by highlighting the effects of temperature on the physicochemical characteristics of the biopolymers. The strength of hydrogen bonds of polymers can be reduced at elevated temperatures. This phenomenon can enhance the availability of active sites of the polymer for binding water molecules, which can increase the amount of monolayer water [35].

According to the literature, reduced temperatures can facilitate the formation of powerful exothermic adsorbent-adsorbate interactions, enhancing the $C$ parameter of Equation (1) [31]. A similar observation was made in the current study. According to the results, increasing the temperature from 5 to $60^{\circ} \mathrm{C}$ enhanced the $\mathrm{C}$ parameter steadily (Equations (3) and (4)). Likewise, a non-regular variation of the $C$ parameter due to temperature variations was observed previously for immature acerola juice powder containing AG.

The $\mathrm{K}$ parameter, which represents the interactions between multilayer molecules and the adsorbent, is prone to range from the energy level of the molecules in liquid water to that of the monolayer. The water multilayers are expected to have liquid water properties when the $\mathrm{K}$ value is approximately one [32]. Similarly, in the current study, the K value of DS powders showed only negligible changes (ranged from 0.8 to 1.2 ).

\section{Conclusions}

This paper described the first attempt to improve the physical stability of date syrup through the incorporation of a natural hydrocolloid, i.e., acacia gum. The results showed that this gum can be successfully incorporated into date syrup as an anti-plasticizer to make the production of date syrup powder feasible. Moreover, it was revealed that increasing the acacia gum concentration (from $30 \%$ to $40 \%, 50 \%$, and $60 \%$ ) enhanced the moisture content, $p_{\mathrm{b}}$, lightness, and Tg of the date syrup powder. On the other hand, increasing the gum concentration produced date syrups with reduced equilibrium moisture and caking degree. For all the DS powders, type III isotherm behavior was observed, which was similar to that of high-sugar food materials. Furthermore, this study revealed 
that Peleg and GAB are appropriate models to fit the experimental data of date syrup acacia gum mixtures. Fitting the experimental data into these models revealed that increasing the acacia gum concentration decreased the monolayer moisture content. According to the findings of this study, food and pharmaceutical industries may consider acacia gum as an effective natural anti-plasticizer to produce a date syrup powder with improved storage properties and reduced caking degree. Besides, replacing chemically produced anti-plasticizers with natural alternatives, such as acacia gum, can improve the market competitiveness of the dried date powder producers through complying with the clean- and green-label policy as well as consumer food trends.

\section{Abbreviations and Nomenclatures}

\begin{tabular}{|c|c|}
\hline${ }^{\circ} \mathrm{Bx}$ & degrees Brix \\
\hline $0 \%$ AG & date syrup with no acacia gum \\
\hline $30 \%$ AG & powder samples containing $70 \%$ date syrup and $30 \%$ acacia gum \\
\hline $40 \%$ AG & powder samples containing $60 \%$ date syrup and $40 \%$ acacia gum \\
\hline $50 \%$ AG & powder samples containing $50 \%$ date syrup and $50 \%$ acacia gum \\
\hline $60 \%$ AG & powder samples containing $40 \%$ date Syrup and $60 \%$ acacia \\
\hline AOAC & Association of Official Analytical Chemists \\
\hline AG & acacia gum \\
\hline$a_{w}$ & water activity \\
\hline $\mathrm{C}$ & a constant in GAB and BET models \\
\hline $\mathrm{CD}$ & caking degree \\
\hline DS & date syrup \\
\hline DS-AG & date syrup- acacia gum mixtures \\
\hline EMC & equilibrium moisture content \\
\hline $\exp$ & experimental \\
\hline GAB & Guggenheim-Anderson-de Boer \\
\hline $\mathrm{H}$ & the height of the vessel used for bulk density analysis \\
\hline HPLC & high-performance liquid chromatography \\
\hline IUPAC & International Union of Pure and Applied Chemistry \\
\hline K & a constant in GAB model \\
\hline $\mathrm{k}_{1}$ & a Peleg model constant \\
\hline $\mathrm{k}_{2}$ & a Peleg model constant \\
\hline $\mathrm{M}_{0}$ & monolayer moisture content \\
\hline $\mathrm{M}_{\mathrm{e}}$ & mean relative percentage deviation modulus \\
\hline $\mathrm{n}_{1}$ & a Peleg model constant \\
\hline $\mathrm{n}_{2}$ & a Peleg model constant \\
\hline$p_{\mathrm{b}}$ & bulk density \\
\hline Pre & predicted \\
\hline $\mathrm{R}$ & radius of the vessel used for bulk density analysis \\
\hline $\mathrm{R}^{2}$ & correlation coefficient \\
\hline RSS & residual sum of squares \\
\hline SEE & standard error of estimate \\
\hline Temp. & temperature \\
\hline $\operatorname{Tg}$ & glass transition temperature \\
\hline $\operatorname{Tgc}$ & endset glass transition \\
\hline Tgi & onset glass transition \\
\hline Tgm & middle glass transition \\
\hline $\mathrm{V}$ & volume of the bulk density measurement vessel \\
\hline
\end{tabular}

Author Contributions: Conceptualization, A.F.; methodology, A.F., M.M., F.B.; validation, A.F., M.M., F.B. and M.G.; formal analysis, A.F., M.M., F.B. and M.G.; investigation, N.M.; resources, A.F.; data curation, N.M, A.F. and M.G.; writing —original draft preparation, N.M. and M.G.; writing—review and editing, M.G. and A.F.; supervision, A.F.; funding acquisition, A.F. All authors have read and agreed to the published version of the manuscript. 
Funding: The APC was funded by RMIT University (the last author) and voucher discounts of acting as a reviewer for MDPI journals (the third author).

Acknowledgments: M.G. would like to appreciate the support of the Ministry of Economic Affairs, project no. 108-EC-17-A-22-0332, Taiwan.

Conflicts of Interest: The authors declare no conflict of interest.

\section{References}

1. Martín-Sánchez, A.M.; Ciro-Gómez, G.; Vilella-Esplá, J.; Pérez-Álvarez, J.Á.; Sayas-Barberá, E. Physicochemical and sensory characteristics of spreadable liver pâtés with annatto extract (bixa orellana L.) and date palm co-products (phoenix dactylifera L.). Foods 2017, 6, 94. [CrossRef] [PubMed]

2. Siddeeg, A.; Zeng, X.A.; Ammar, A.F.; Han, Z. Sugar profile, volatile compounds, composition and antioxidant activity of Sukkari date palm fruit. J. Food Sci. Technol. 2019, 56, 754-762. [CrossRef] [PubMed]

3. Ben-Amor, R.; Dhouibi, M.H.; Aguayo, E. Hot water treatments combined with cold storage as a tool for ectomyelois ceratoniae mortality and maintenance of deglet noor palm date quality. Postharvest Biol. Technol. 2016, 112, 247-255. [CrossRef]

4. Seerangurayar, T.; Manickavasagan, A.; Al-Ismaili, A.M.; Al-Mulla, Y.A. Effect of carrier agents on physicochemical properties of foam-mat freeze-dried date powder. Dry. Technol. 2017, 1-12. [CrossRef]

5. Eid, N.M.S.; Al-Awadi, B.; Vauzour, D.; Oruna-Concha, M.J.; Spencer, J.P.E. Effect of cultivar type and ripening on the polyphenol content of date palm fruit. J. Agric. Food Chem. 2013, 61, 2453-2460. [CrossRef]

6. Ghnimi, S.; Umer, S.; Karim, A.; Kamal-Eldin, A. Date fruit (Phoenix dactylifera L.): An underutilized food seeking industrial valorization. NFS J. 2017, 6, 1-10. [CrossRef]

7. Truong, V.; Bhandari, B.R.; Howes, T. Optimization of co-current spray drying process of sugar-rich foods. Part I-Moisture and glass transition temperature profile during drying. J. Food Eng. 2005, 71, 55-65. [CrossRef]

8. Ahmed, J.; Ramaswamy, H.S. Physico-chemical properties of commercial date pastes (Phoenix dactylifera). J. Food Eng. 2006, 76, 348-352. [CrossRef]

9. Jaya, S.; Das, H. Effect of maltodextrin, glycerol monostearate and tricalcium phosphate on vacuum dried mango powder properties. J. Food Eng. 2004, 63, 125-134. [CrossRef]

10. Nieto Calvache, J.E.; Soria, M.; DeEscalada Pla, M.F.; Gerschenson, L.N. Optimization of the production of dietary fiber concentrates from by-products of papaya (Carica papaya L. Var. Formosa) with microwave assistance. Evaluation of its physicochemical and functional characteristics. J. Food Process. Preserv. 2017, 41, e13071.

11. Ganesan, V.; Rosentrater, K.A.; Muthukumarappan, K. Flowability and handling characteristics of bulk solids and powders-A review with implications for DDGS. Biosyst. Eng. 2008, 101, 425-435. [CrossRef]

12. Mosquera, L.H.; Moraga, G.; Martínez-Navarrete, N. Critical water activity and critical water content of freeze-dried strawberry powder as affected by maltodextrin and arabic gum. Food Res. Int. 2012, 47, 201-206. [CrossRef]

13. Musa, H.H.; Ahmed, A.A.; Musa, T.H. Chemistry, biological, and pharmacological properties of gum arabic. In Bioactive Molecules in Food; Springer: Berlin, Germany, 2018; pp. 1-18.

14. Erben, M.; Pérez, A.A.; Osella, C.A.; Alvarez, V.A.; Santiago, L.G. Impact of gum arabic and sodium alginate and their interactions with whey protein aggregates on bio-based films characteristics. Int. J. Biol. Macromol. 2019, 125, 999-1007. [CrossRef] [PubMed]

15. Gavahian, M.; Chen, Y.M.; Mousavi Khaneghah, A.; Barba, F.J.; Yang, B.B. In-pack sonication technique for edible emulsions: Understanding the impact of acacia gum and lecithin emulsifiers and ultrasound homogenization on salad dressing emulsions stability. Food Hydrocoll. 2018, 83, 79-87. [CrossRef]

16. Patel, S.; Goyal, A. Applications of natural polymer gum Arabic: A review. Int. J. Food Prop. 2015, 18, 986-998. [CrossRef]

17. Samborska, K.; Gajek, P.; Kamińska-Dwórznicka, A. Spray drying of honey: The effect of drying agents on powder properties. Polish J. Food Nutr. Sci. 2015, 65, 109-118. [CrossRef]

18. Fikry, M.; Al-Awaadh, A.M. Characteristics of dynamics sorption isotherms of date flesh powder rich in fiber. Int. J. Food Eng. 2016, 12, 469-480. [CrossRef] 
19. Farahnaky, A.; Mansoori, N.; Majzoobi, M.; Badii, F. Physicochemical and sorption isotherm properties of date syrup powder: Antiplasticizing effect of maltodextrin. Food Bioprod. Process. 2016, 98, 133-141. [CrossRef]

20. Gao, J.; Brennan, M.A.; Mason, S.L.; Brennan, C.S. Effects of sugar substitution with "Stevianna" on the sensory characteristics of muffins. J. Food Qual. 2017, 2017,1-11. [CrossRef]

21. Sablani, S.S.; Shrestha, A.K.; Bhandari, B.R. A new method of producing date powder granules: Physicochemical characteristics of powder. J. Food Eng. 2008, 87, 416-421. [CrossRef]

22. Angel, R.C.M.; Espinosa-Muñoz, L.C.; Aviles-Aviles, C.; González-García, R.; Moscosa-Santillán, M.; Grajales-Lagunes, A.; Abud-Archila, M. Spray-drying of passion fruit juice using lactose-maltodextrin blends as the support material. Brazilian Arch. Biol. Technol. 2009, 52, 1011-1018. [CrossRef]

23. Afshari-Jouybari, H.; Farahnaky, A. Evaluation of photoshop software potential for food colorimetry. J. Food Eng. 2011, 106, 170-175. [CrossRef]

24. Gavahian, M.; Farahnaky, A.; Javidnia, K.; Majzoobi, M. Comparison of ohmic-assisted hydrodistillation with traditional hydrodistillation for the extraction of essential oils from thymus vulgaris L. Innov. Food Sci. Emerg. Technol. 2012, 14, 85-91. [CrossRef]

25. Rizvi, S.S.H. Thermodynamic properties of foods in dehydration. In Engineering Properties of Foods; Taylor and Francis: New York, NY, USA, 1995; Volume 2, p. 123.

26. Gavahian, M.; Chu, Y.H.; Farahnaky, A. Effects of ohmic and microwave cooking on textural softening and physical properties of rice. J. Food Eng. 2019, 243, 114-124. [CrossRef]

27. Chowdhury, M.M.I.; Huda, M.D.; Hossain, M.A. Moisture sorption isotherms for mungbean (Vigna radiata L). J. Food Eng. 2006, 74, 462-467. [CrossRef]

28. Al-Muhtaseb, A. Water sorption isotherms of starch powders Part 1: Mathematical description of experimental data. J. Food Eng. 2004, 61, 297-307. [CrossRef]

29. Muthukumarappan, K.; Swamy, G.J. Glass transition thermodynamics and kinetics. In Glass Transition and Phase Transitions in Food and Biological Materials; Ahmed, J., Ed.; John Wiley \& Sons, Ltd.: Chichester, UK, 2017; pp. 31-47. ISBN 9781118935682.

30. Al-Hooti, S.N.; Sidhu, J.S.; Al-Saqer, J.M.; Al-Othman, A. Chemical composition and quality of date syrup as affected by pectinase/cellulase enzyme treatment. Food Chem. 2002, 79, 215-220. [CrossRef]

31. Gabas, A.L.; Telis, V.R.N.; Sobral, P.J.A.; Telis-Romero, J. Effect of maltodextrin and arabic gum in water vapor sorption thermodynamic properties of vacuum dried pineapple pulp powder. J. Food Eng. 2007, 82, 246-252. [CrossRef]

32. Pérez-Alonso, C.; Beristain, C.I.; Lobato-Calleros, C.; Rodríguez-Huezo, M.E.; Vernon-Carter, E.J. Thermodynamic analysis of the sorption isotherms of pure and blended carbohydrate polymers. J. Food Eng. 2006, 77, 753-760. [CrossRef]

33. Righetto, A.M.; Netto, F.M. Effect of encapsulating materials on water sorption, glass transition and stability of juice from immature acerola. Int. J. Food Prop. 2005, 8, 337-346. [CrossRef]

34. Ayranci, E.; Duman, O. Moisture sorption isotherms of cowpea (Vigna unguiculata L. Walp) and its protein isolate at 10, 20 and $30^{\circ} \mathrm{C}$. J. Food Eng. 2005, 70, 83-91. [CrossRef]

35. Farahnaky, A.; Ansari, S.; Majzoobi, M. Effect of glycerol on the moisture sorption isotherms of figs. J. Food Eng. 2009, 93, 468-473. [CrossRef]

36. Hazaveh, P.; Mohammadi Nafchi, A.; Abbaspour, H. The effects of sugars on moisture sorption isotherm and functional properties of cold water fish gelatin films. Int. J. Biol. Macromol. 2015, 79, 370-376. [CrossRef] [PubMed]

37. Aviara, N.A.; Ajibola, O.O.; Aregbesola, O.A.; Adedeji, M.A. Moisture sorption isotherms of sorghum malt at 40 and $50{ }^{\circ}$ C. J. Stored Prod. Res. 2006, 42, 290-301. [CrossRef]

38. Alhamdan, A.M.; Hassan, B.H. Water sorption isotherms of date pastes as influenced by date cultivar and storage temperature. J. Food Eng. 1999, 39, 301-306. [CrossRef]

(C) 2020 by the authors. Licensee MDPI, Basel, Switzerland. This article is an open access article distributed under the terms and conditions of the Creative Commons Attribution (CC BY) license (http://creativecommons.org/licenses/by/4.0/). 